\title{
Cell-Based Therapies for Heart Failure
}

\author{
Antonio Carlos Campos de Carvalho ${ }^{1,2,3 *}$, Tais H. Kasai-Brunswick ${ }^{2,3}$ and \\ Adriana Bastos Carvalho ${ }^{1,3}$
}

${ }^{1}$ Laboratory of Cellular and Molecular Cardiology, Institute of Biophysics Carlos Chagas Filho, Federal University of Rio de Janeiro, Rio de Janeiro, Brazil, ${ }^{2}$ National Center of Structural Biology and Bioimaging (CENABIO), Federal University of Rio de Janeiro, Rio de Janeiro, Brazil, ${ }^{3}$ National Institute of Science and Technology in Regenerative Medicine, Federal University of Rio de Janeiro, Rio de Janeiro, Brazil

Heart failure has reached epidemic proportions with the advances in cardiovascular therapies for ischemic heart diseases and the progressive aging of the world population. Efficient pharmacological therapies are available for treating heart failure, but unfortunately, even with optimized therapy, prognosis is often poor. Their last therapeutic option is, therefore, a heart transplantation with limited organ supply and complications related to immunosuppression. In this setting, cell therapies have emerged as an alternative. Many clinical trials have now been performed using different cell types and injection routes. In this perspective, we will analyze the results of such trials and discuss future perspectives for cell therapies as an efficacious treatment of heart failure.

\section{OPEN ACCESS}

Edited by:

Francesco Rossi,

University of Campania Luigi Vanvitelli,

Italy

Reviewed by: Konrad Urbanek Magna Græcia University of

Catanzaro, Italy

Antonio Paolo Beltrami,

University of Udine, Italy

*Correspondence:

Antonio Carlos Campos de Carvalho acarlos@biof.ufr.jbr

Specialty section:

This article was submitted to Cardiovascular and Smooth Muscle Pharmacology, a section of the journal Frontiers in Pharmacology

Received: 13 December 2020 Accepted: 11 February 2021

Published: 12 April 2021

Citation:

Campos de Carvalho AC,

Kasai-Brunswick TH and

Bastos Carvalho A (2021) Cell-Based

Therapies for Heart Failure.

Front. Pharmacol. 12:641116.

doi: 10.3389/fphar.2021.641116
Keywords: cell therapies, heart failure, bone marrow cells, adult stem cells, pluripotent cells (Min5-Max 8)

\section{INTRODUCTION}

Cardiovascular diseases (CVD) are still the major cause of death in the world. The Global Burden of Disease (ghdx.healthdata.org) reports over 18.5 million deaths by CVD in the world in 2019, corresponding to $32.8 \%$ of all deaths. For comparison, in the years 1990 and 2000, these numbers were, respectively, 12 and 13.9 million deaths, corresponding to 25.9 and $27.5 \%$ of all deaths. People living with heart failure were estimated at 37.7 million worldwide in 2010 (Wollert et al., 2004) and are now estimated to have reached 63.3 million (AME Medical Journal, 2020). Mortality from HF is hard to estimate since the cause of death is usually attributed to the causative etiology, but 5-year survival rates for HF are similar to those of cancer and stroke (Askoxylakis et al., 2010).

The main etiologies for heart failure are ischemic, valvular, and hypertensive heart diseases, and primary and secondary cardiomyopathies. A detailed discussion of each etiology is beyond the scope of this perspective, and interested readers are referred to a review by Ziaeian and Fonarow (Ziaeian and Fonarow, 2016). According to the ESC guidelines (Ponikowski et al., 2016), heart failure is "a clinical syndrome characterized by typical symptoms (e.g., breathlessness, ankle swelling, and fatigue) that may be accompanied by signs (e.g., elevated jugular venous pressure, pulmonary crackles, and peripheral edema) caused by a structural and/or functional cardiac abnormality, resulting in a reduced cardiac output and/or elevated intracardiac pressures at rest or during stress." The guidelines define a new term for heart failure (HF) in patients who have an ejection fraction (EF) between 40 and 49\%: HF with midrange EF-HFmrEF. This new category now covers all ranges of EF in $\mathrm{HF}$ patients. $\mathrm{HF}$ with reduced $\mathrm{EF}(\mathrm{HFrEF})$ is defined as having ejection fractions $\leq 40 \%$ and $\mathrm{HF}$ with preserved $\mathrm{EF}$ (HFpEF) as $\geq 50 \%$.

Although there are many classes of pharmacologic drugs that are commonly used to treat $\mathrm{HF}$ and growing numbers of new molecules and signaling pathways are being investigated-for detailed information see (Yancy et al., 2016; Cresci et al., 2019), a number of HF patients do not respond adequately to optimal pharmacologic therapy and progress to congestive heart failure, when assist 


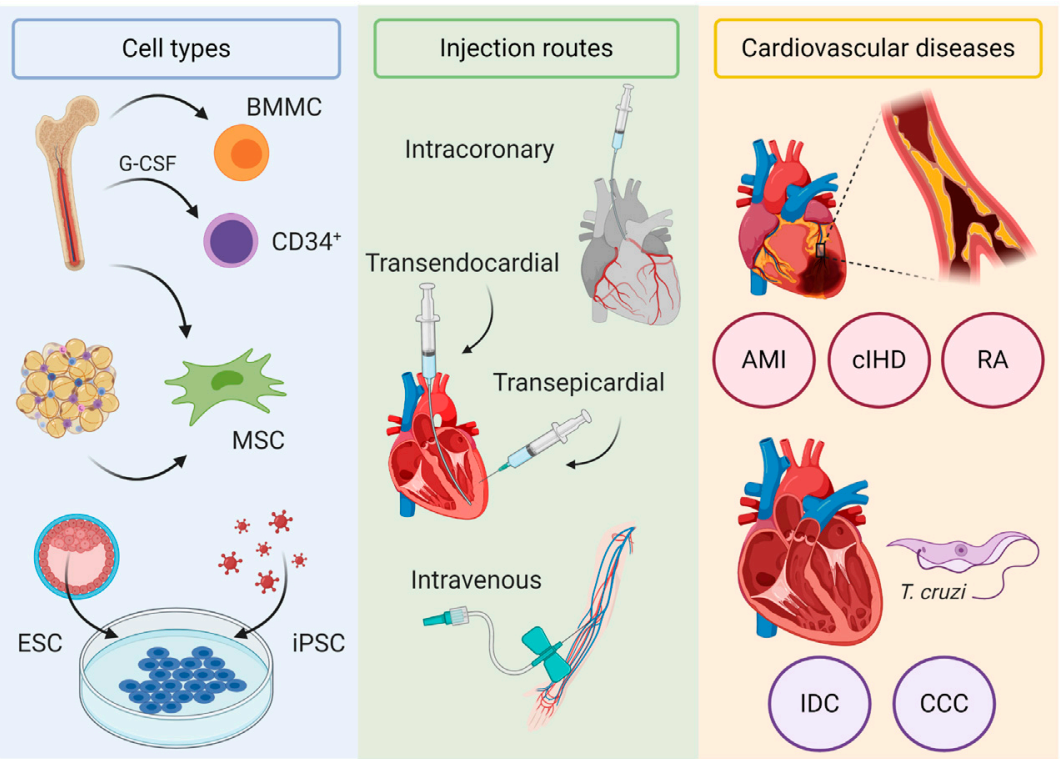

FIGURE 1 | Cell-based therapies for heart failure. Cell types used in clinical trials include bone marrow mononuclear cells (BMMC), CD34 ${ }^{+}$mobilized with G-CSF, bone marrow and adipose tissue-derived mesenchymal stromal cells (MSC), embryonic stem cells (ESC), and induced pluripotent stem cells (iPSC). Injection routes include intracoronary, transendocardial, and transepicardial routes, which deliver cells directly in the myocardium, and intravenously. Cardiovascular diseases evaluated in clinical trials include ischemic (acute myocardial infarction (AMI), chronic ischemic heart disease (clHD), and refractory angina (RA)) and nonischemic cardiomyopathies (idiopathic dilated cardiomyopathy (IDC) and chronic chagasic cardiomyopathy (CCC)).

devices followed by heart transplantation are the only possible therapy. Donor organ shortage and complications related to continuous immunosuppression of these patients significantly limit this therapeutic option stimulating the search for new therapies. In this setting, cell-based therapies emerged as a potential treatment at the turn of the millennium. This perspective will review the clinical trials performed to date using different cell types and injection routes in distinct types of cardiac diseases that lead to heart failure (see Figure 1). Most of our analysis will focus on cell therapies for HFrEF and HFmrEF, where there is loss of cardiomyocytes due to various myocardial insults and cell-based therapies attempt to regenerate the lost cells.

\section{CELL-BASED THERAPIES FOR ISCHEMIC HEART DISEASE}

Ischemic heart disease (IHD) is characterized by an unbalance between oxygen demand and supply, resulting in hypoxia that ultimately leads to cell death and loss of cardiomyocytes. Cellbased therapies were, therefore, initially proposed based on the assumption that the injected cell types could substitute or regenerate the lost cardiomyocytes. A pioneering attempt was the use of skeletal myoblasts by the group of Philippe Menasché in France (Menasché et al., 2001). At the turn of the millennium, research groups in Germany and Brazil started small clinical trials injecting autologous bone marrow-derived mononuclear cells (ABMMC) in patients that had suffered myocardial infarction either by intracoronary (Assmus et al., 2002; Strauer et al., 2002) or transendocardial (Perin et al., 2003; Gowdak et al., 2005) route. Results from these preliminary small trials suggested small functional cardiac improvements based on evaluation of left ventricular ejection fraction (LVEF) and indicated both procedures to be safe. Stimulated by these initial promising results, the number of clinical trials using the ABMMC significantly increased, and larger, more controlled trials were performed, supporting the initial positive results (Britten et al., 2003; Wollert et al., 2004; Schächinger et al., 2006a; Dill et al., 2009; Honold et al., 2012; Assmus and Zeiher, 2013). In 2006, two manuscripts, published back-to-back in the New England Journal of Medicine, reported discordant results on the effects of ABMMC in the setting of acute myocardial infarction (Lunde et al., 2006) (Schächinger et al., 2006b). During the following years more clinical trials using ABMMC in IHD were performed (Janssens et al., 2006; Grajek et al., 2010), as reported in metaanalysis studies (Lipinski et al., 2007; Martin-Rendon et al., 2008; Delewi et al., 2014; Assmus et al., 2015). For the rest of the decade, the prevailing view, although contested, was that bone-marrowderived mononuclear cells were capable of some degree of heart repair after insult by IHD. In the following decade, at least ten randomized and multicenter trials using mostly ABMMC, but also selected bone marrow cells, in IHD occurred in the world. All of these trials did not find additional benefits to standard therapy (Traverse et al., 2011; Perin et al., 2012; Traverse et al., 2012; Sürder et al., 2013; Choudry et al., 2016; Sürder et al., 2016; Quyyumi et al., 2017; Wollert et al., 2017; Fernández-Avilés et al., 2018; Nicolau et al., 2018), mostly in acute but one in chronic 
IHD using either the intracoronary or the transendocardial injection route. Finally, the BAMI trial, a European effort to test the efficacy of ABMMC in acute myocardial infarction (AMI), did not meet planned endpoints relevant to clinical outcomes (mortality and MACE) between patients in the ABMMC and control groups due to low enrollment and low mortality (Mathur et al., 2020). As written in a thoughtful commentary by Roberto Bolli about the BAMI trial, cell therapy with bone marrow-derived mononuclear cells for AMI patients should "rest in peace" (Bolli, 2020).

But what about other types of IHD, such as chronic IHD (cIHD) and refractory angina? In chronic IHD, results are variable depending on cell type. Perin et al. have reported no benefit with a large ABMMC trial and positive results with a dose escalation study using high doses of allogenic bone marrowderived mesenchymal stromal cells (MSC) in cIHD (Perin et al., 2012; Perin et al., 2015). Other studies performed by Hare's group (Hare et al., 2012; Suncion et al., 2014) using autologous and allogeneic MSC injected transendocardially showed limited effects on global heart function in cIHD. A more robust study using a mixture of $\mathrm{CD}^{+} 0^{+} \mathrm{MSC}$ and $\mathrm{CD} 45^{+} / \mathrm{CD} 14^{+}$bone marrow-derived cells delivered by transendocardial injection showed significant decreases in combined clinical outcomes that included composite all-cause death, cardiovascular hospital admissions, and unplanned clinical visits to treat decompensated heart failure (Patel et al., 2016). Two other studies using autologous bone marrow-derived MSC injected intramyocardially also found significant differences in surrogate endpoints such as reduction in left ventricular end systolic and diastolic volumes (LVSEV and LVEDV), but LVEF and myocardial mass did not vary significantly between cell and control groups (Teerlink et al., 2017) in one study, but reached statistical difference in the other (Mathiasen et al., 2015). It seems, therefore, that selected bone marrow cells directly injected in the myocardium may have a salutary effect in cIHD patients with heart failure. Nonetheless, most of these studies were phase 1-2 trials, and we should still wait for larger phase- 3 trials.

Refractory angina is another type of IHD where cell-based therapies offer hope. In this setting the most important trials used selected $\mathrm{CD} 34^{+}$cells derived from the bone marrow. Positive results were consistently seen in phase 1-2 trials (Losordo et al., 2007, Losordo et al., 2011; Povsic et al., 2016), but the phase-3 trial had to be curtailed due to withdrawal of funding from industry (Henry et al., 2018). Since CD34 is a marker of endothelial progenitor cells (Asahara et al., 1997) the use of these cells to promote angiogenesis in the setting of IHD is rational, and unfortunately for the field of cell-based therapies the phase- 3 clinical trial could not be completed, although pooled data from all the trials mentioned above showed significant increase in total exercise time, decreased angina frequency, and reduced 24-month mortality in patients receiving the cell therapy (Henry et al., 2018)

Other, non-marrow-derived cell types have also been tested in patients with IHD. Freshly isolated liposuction aspirate cells, MSC derived from adipose tissue, and putative cardiac stem/ progenitor cells reached clinical studies but did not go beyond safety trials (Chugh et al., 2012; Makkar et al., 2012; Malliaras et al., 2014; Perin et al., 2014; Kastrup et al., 2017) for various reasons, including the disputed existence of a cardiac stem/ progenitor cell (Berlo and Molkentin, 2014; Cai and Molkentin, 2017; Vicinanza et al., 2018; Aquila et al., 2019). The use of cells truly capable of generating new cardiomyocytes for heart repair, the pluripotent stem cells (either embryonic or induced pluripotent stem cells (iPSC)), waits further preclinical safety studies, although a small number of patients undergoing coronary artery bypass grafting (CABG) have received a fibrin patch of cardiac progenitor cells derived from human embryonic stem cells (Menasché et al., 2015, Menasché et al., 2018).

\section{CELL-BASED THERAPIES FOR NONISCHEMIC CARDIOMYOPATHIES}

In the nonischemic cardiomyopathies, the major cause of the disease lies not in the blood supply to the heart but rather in the mechanical or electrical dysfunction of cardiomyocytes, although microvascular dysfunction and significant impairment in coronary blood flow reserve have been demonstrated in most patients with idiopathic dilated cardiomyopathy (Neglia et al., 2002; Canetti et al., 2003) . Cardiomyopathies can be classified as hypertrophic, dilated, restrictive, or arrhythmogenic. Cell-based therapies have been studied in two types of dilated cardiomyopathies: idiopathic dilated cardiomyopathy and chronic chagasic cardiomyopathy.

\section{Cell-Based Therapies for Idiopathic Dilated Cardiomyopathy}

Since nonischemic dilated cardiomyopathies are one of the leading causes of advanced heart failure and account for more than $50 \%$ of heart transplants, cell-based therapies were also intensively investigated in this setting. There have been a number of small cell therapy trials in idiopathic dilated cardiomyopathy (IDC) using ABMMC that ascertained the safety and feasibility of the procedure (Seth et al., 2006; Fischer-Rasokat et al., 2009; Martino et al., 2010; Sant'Anna et al., 2014). Larger trials using ABMMC in IDC had conflicting results. Seth et al. (Seth et al., 2010) showed that, after 3 years, a total of 41 patients who received cells (versus 40 patients in the control arm) had a significant increase in LVEF and quality of life, although mortality did not differ between cell and control groups. On the other hand, Martino et al. (Martino et al., 2015) showed in 115 patients that completed the multicenter study that there were no significant differences in LVEF, quality of life, or mortality between groups. In both studies, cells were delivered by intracoronary injection but using slightly different methods. Other large trials in patients with IDC were performed using CD $34^{+}$cells derived from the bone marrow, delivered either by intracoronary or intramyocardial injection. When $\mathrm{CD} 34^{+}$were used, the cell-treated group showed increased LVEF, 6 min walking distance, decreased NT-proBNP levels and, surprisingly, given the small patient sample (55 in total), even a significant decrease in the combined secondary endpoint of 1year mortality and heart transplantation (Vrtovec et al., 2011). A 
larger study enrolling 110 IDC patients followed for 5 years by the same group reported similar results (Vrtovec et al., 2013a). They further showed that injecting the $\mathrm{CD}^{+} 4^{+}$cells by the transendocardial route led to more cell retention and greater effects on LVEF, 6 min walking distance, and NT-proBNP levels than injecting by intracoronary route (Vrtovec et al., 2013b). MSC derived from bone marrow were also used in IDC patients. One trial using the same mix of $\mathrm{CD} 90^{+} \mathrm{MSC}$ and $\mathrm{CD} 45^{+} / \mathrm{CD} 14^{+}$ cells described above for ischemic heart disease (Patel et al., 2016) found that these cells did not improve clinical outcomes in nonischemic heart disease (Henry et al., 2014). A trial comparing the effects of autologous and allogeneic bone marrow MSC in IDC found greater, clinically meaningful efficacy with allogeneic cells (Hare et al., 2016), suggesting that these cells rather than the autologous should be tested in larger, more robust trials. In summary, the results of bone marrowderived cell therapies in IDC seemed highly variable with the exception of the trials that used $\mathrm{CD} 34^{+}$selected cells, as was the case for the refractory angina patients. Since microvascular dysfunction and significant impairment in coronary blood flow reserve have been demonstrated in most patients with IDC (Neglia et al., 2002; Canetti et al., 2003), it is reasonable to assume that cells capable to promote angiogenesis, as CD $34^{+}$ cells, could bring salutary effects to patients with IDC. Once again, we can only regret that larger, double-blinded, randomized, placebo-controlled, and multicenter trials have not been performed to definitely test the efficacy of these cells in IDC patients.

\section{Cell-Based Therapies for Chronic Chagasic Cardiomyopathy}

Chronic chagasic cardiomyopathy (CCC) is a dilated cardiomyopathy caused by the parasite Trypanosoma cruzi, endemic in many regions in Latin America. Although the parasite, the transmitting vector, and the disease were described more than 100 years ago by Carlos Chagas (Chagas, 1909), disease pathogenesis mechanisms are still discussed, due to their multifactorial nature. A review of Chagas disease pathogenesis is beyond the scope of this perspective, but it is important to cite parasite persistence, autoimmunity, and microvascular alterations as pathogenic mechanisms (Tanowitz et al., 2009). Although bone marrow-derived cell therapies are not expected to eliminate parasites, their immunomodulatory and angiogenic capacities have been documented (Heldring et al., 2015). Furthermore, the use of bone marrow-derived cell therapies in CCC has been supported by innumerous preclinical model experiments (Soares et al., 2004; Goldenberg et al., 2008; Goldenberg et al., 2009; Soares et al., 2011; Jasmin et al., 2012; Jasmin et al., 2014; Iacobas et al., 2018). Based on promising results obtained in animal models of CCC treated with bone marrow-derived mononuclear cells, Vilas-Boas et al. conducted the first cell therapy trial in patients by intracoronary injection of ABMMC (Vilas-Boas et al., 2006; Vilas-Boas et al., 2011). This initial 28-patient trial proved the procedure to be safe and potentially efficacious, based on improvements in NYHA class, quality of life questionnaire,
6 min walking test, and LVEF. Based on that, a larger multicenter, randomized, placebo-controlled, and doubleblinded trial was performed, evaluating 183 CCC patients (Santos et al., 2012). Results were disappointing since no statistical differences were observed between the cell-treated and placebo groups in all parameters listed above. To our knowledge no other clinical trials with cell therapies have been performed in CCC patients.

\section{DISCUSSION}

Clinical trials of cell-based therapies in heart failure have been performed using different cell types, cell doses, injection routes, and disease states. In addition, the majority of the trials performed recruited a small number of patients. For a comprehensive list of the clinical trials performed, see Supplementary Appendix A1 in the Appendix. All of these factors severely limited the conclusions about efficacy of these trials and the many, indeed excessive, meta-analyses performed did not take this profound heterogeneity into account. One clear result from all the clinical trials performed to date is that the procedures are safe and feasible, no matter what cell type or injection route is used for the attempted therapy of the distinct disease states.

The most commonly used cell type was undoubtedly a mixture of cells derived from the bone marrow, the mononuclear cell fraction, extracted directly by marrow aspiration or mobilized to the periphery by granulocyte colony stimulating factor (G-CSF). As mentioned above, the prevailing view, currently, is that the bone marrow mononuclear cell fraction does not bring additional benefit to patients, with either ischemic or nonischemic heart disease, over conventional pharmacologic therapy. The last, long waited BAMI trial could not be completed and has put to rest any hopes that these cells might impact clinically meaningful endpoints. Other cell types are still waiting the final verdict, but with the exception of the $\mathrm{CD} 34^{+}$cells (limited to angiogenesis) it is unlikely that any other marrow-derived cell type may bring real benefits to heart failure patients. In our opinion, hope lies in pluripotent stem cells, the only ones capable of differentiation into any cell type. In fact, robust engraftment and muscularization have been shown with human embryonic and induced pluripotent stem cell-derived cardiomyocytes in AMI in nonhuman primates (Chong et al., 2014; Shiba et al., 2016; Liu et al., 2018), although transient arrhythmias have been recorded and further preclinical safety studies are therefore required. Nonetheless, a small number of patients undergoing coronary artery bypass grafting (CABG) have received a fibrin patch of cardiac progenitor cells derived from human embryonic stem cells (Menasché et al., 2015, Menasché et al., 2018) without serious adverse events being recorded. Injection routes have varied extensively among the clinical trials performed. The two most used routes were the intracoronary and the intramyocardial, the last one either by endocardial or epicardial access. In a small number of trials, intravenous injection of cells has also been attempted (Butler et al., 2016). The intramyocardial route seems to be more 
effective in clinical trials that compared it to intracoronary delivery of the cells (Brunskill et al., 2009; Vrtovec et al., 2013b; Mozid et al., 2014). At any rate, cell delivery and survival in clinical trials have been very limited independent of the injection route chosen (Hofmann et al., 2005; Fonseca et al., 2011; Spoel et al., 2011).

Cell doses have also varied among clinical trials but have usually been in the range of $10^{7}-10^{9}$ cells either using unselected or selected bone marrow-derived cells (Sanganalmath and Bolli, 2013). A few studies have compared different cell doses and found that lower cell doses were more efficient than the higher doses (Hamamoto et al., 2009; Hare et al., 2012).

In summary, almost more than 20 years after the first clinical trials of cell-based therapies for heart disease were started, the field has yet to demonstrate a robust result that would allow cell therapies to be incorporated into clinical practice. Throughout this period, it became evident that unselected bone marrow cells are not an adequate cell source. Mesenchymal stromal cells offer limited improvement and, in our opinion, will not reach clinical practice. CD $34^{+}$cells seem to work for refractory angina, but the efficacy trial was never completed. We envisage that when the transient arrhythmias induced by cardiomyocytes derived from pluripotent stem cells in the nonhuman primates are better understood and controlled, these cells will be capable to enter clinical trials and hopefully allow cardiologists to offer a viable option for heart failure patients who are candidates for assist devices and heart transplantation.

\section{REFERENCES}

AME Medical Journal (2020). Global epidemiology and future trends of heart failure - Lippi- AME Medical Journal undefined. Available at: http://amj. amegroups.com/article/view/5475/pdf (Accessed November 25, 2020).

Aquila, I., Cianflone, E., Scalise, M., Marino, F., Mancuso, T., Filardo, A., et al. (2019). c-kit Haploinsufficiency impairs adult cardiac stem cell growth, myogenicity and myocardial regeneration. Cell Death Dis. 10, 436. doi:10. 1038/s41419-019-1655-5

Asahara, T., Murohara, T., Sullivan, A., Silver, M., van der Zee, R., Li, T., et al. (1997). Isolation of putative progenitor endothelial cells for angiogenesis. Science. 275, 964-967. doi:10.1126/science.275.5302.964

Askoxylakis, V., Thieke, C., Pleger, S. T., Most, P., Tanner, J., Lindel, K., et al. (2010). Long-term survival of cancer patients compared to heart failure and stroke: a systematic review. Bmc Cancer. 10, 105. doi:10.1186/1471-240710-105

Assmus, B., and Zeiher, A. M. (2013). Early cardiac retention of administered stem cells determines clinical efficacy of cell therapy in patients with dilated cardiomyopathy. Circ Res. 112, 6-8. doi:10.1161/circresaha.112.300341

Assmus, B., Schächinger, V., Teupe, C., Britten, M., Lehmann, R., Döbert, N., et al. (2002). Transplantation of progenitor cells and regeneration enhancement in acute myocardial infarction (TOPCARE-AMI). Circulation. 106, 3009-3017. doi:10.1161/01.cir.0000043246.74879.cd

Assmus, B., Dimmeler, S., and Zeiher, A. M. (2015). Cardiac cell therapy: lost in meta-analyses. Circ Res. 116, 1291-1292. doi:10.1161/circresaha.115.306330

Berlo, J. H. V., and Molkentin, J. D. (2014). An emerging consensus on cardiac regeneration. Nat. Med. 20, 1386-1393. doi:10.1038/nm.3764

Bolli, R (2020). Cell therapy for acute myocardial infarction: requiescat in pace. Eur. Heart J. 41, 3711-3714. doi:10.1093/eurheartj/ehaa802

Britten, M. B., Abolmaali, N. D., Assmus, B., Lehmann, R., Honold, J., Schmitt, J., et al. (2003). Infarct remodeling after intracoronary progenitor cell treatment in patients with acute myocardial infarction (TOPCARE-AMI): mechanistic

\section{DATA AVAILABILITY STATEMENT}

The original contributions presented in the study are included in the article/Supplementary Material; further inquiries can be directed to the corresponding authors.

\section{ETHICS STATEMENT}

Ethical review and approval was not required for the study on human participants in accordance with the local legislation and institutional requirements. The patients/participants provided their written informed consent to participate in this study.

\section{AUTHOR CONTRIBUTION}

All authors contributed to the text. AC elaborated the figure and TB the table.

\section{SUPPLEMENTARY MATERIAL}

The Supplementary Material for this article can be found online at: https://www.frontiersin.org/articles/10.3389/fphar.2021.641116/ full\#supplementary-material.

insights from serial contrast-enhanced magnetic resonance imaging. Circulation. 108, 2212-2218. doi:10.1161/01.cir.0000095788.78169.af

Brunskill, S. J., Hyde, C. J., Doree, C. J., Watt, S. M., and Martin-Rendon, E. (2009). Route of delivery and baseline left ventricular ejection fraction, key factors of bone-marrow-derived cell therapy for ischemic heart disease. Eur. J. Heart Fail. 11, 887-896. doi:10.1093/eurjhf/hfp101

Butler, J., Epstein, S. E., Greene, S. J., Quyyumi, A. A., Sikora, S., Kim, R. J., et al. (2017). Intravenous allogeneic mesenchymal stem cells for nonischemic cardiomyopathy. Circ. Res. 120, 332-340. doi:10.1161/CIRCRESAHA.116. 309717

Cai, C-L., and Molkentin, J. D. (2017). The elusive progenitor cell in cardiac regeneration: slip slidin' away. Circ. Res. 120, 400-406. doi:10.1161/ CIRCRESAHA.116.309710

Canetti, M., Akhter, M. W., Lerman, A., Karaalp, I. S., Zell, J. A., Singh, H., et al. (2003). Evaluation of myocardial blood flow reserve in patients with chronic congestive heart failure due to idiopathic dilated cardiomyopathy. Am. J. Cardiol. 92, 1246-1249. doi:10.1016/j.amjcard.2003.08.002

Chagas, C. (1909). Nova tripanozomiaze humana: estudos sobre a morfolojia e o ciclo evolutivo do Schizotrypanum cruzi n. gen., n. sp., ajente etiolojico de nova entidade morbida do homem. Mem. Inst. Oswaldo Cruz. 1, 159-218. doi:10. 1590/s0074-02761909000200008

Chong, J. J., Yang, X., Don, C. W., Minami, E., Liu, Y. W., Weyers, J. J., et al. (2014). Human embryonic-stem-cell-derived cardiomyocytes regenerate non-human primate hearts. Nature. 510, 273-277. doi:10.1038/nature13233

Choudry, F., Hamshere, S., Saunders, N., Veerapen, J., Bavnbek, K., Knight, C., et al. (2016). A randomized double-blind control study of early intra-coronary autologous bone marrow cell infusion in acute myocardial infarction: the REGENERATE-AMI clinical trial†. Eur. Heart J. 37, 256-263. doi:10.1093/ eurheartj/ehv493

Chugh, A. R., Beache, G. M., Loughran, J. H., Mewton, N., Elmore, J. B., Kajstura, J., Pappas, P., et al. (2012). Administration of cardiac stem cells in patients with ischemic cardiomyopathy: the SCIPIO trial: surgical aspects and interim analysis of myocardial function and viability by magnetic 
resonance. Circulation. 126, S54-S64. doi:10.1161/circulationaha.112. 092627

Cresci, S., Pereira, N. L., Ahmad, F., Byku, M., de las Fuentes, L., Lanfear, D. E., et al. (2019). Heart failure in the era of precision medicine: a scientific statement from the american heart association. Circ. Genom. Precis. Med. 12, 458-485. doi:10. 1161/hcg.0000000000000058

Delewi, R., Hirsch, A., Tijssen, J. G., Schächinger, V., Wojakowski, W., Roncalli, J., et al. (2014). Impact of intracoronary bone marrow cell therapy on left ventricular function in the setting of ST-segment elevation myocardial infarction: a collaborative meta-analysis. Eur. Heart J. 35, 989-998. doi:10. 1093/eurheartj/eht372

Dill, T., Schächinger, V., Rolf, A., Möllmann, S., Thiele, H., Tillmanns, H., et al. (2009). Intracoronary administration of bone marrow-derived progenitor cells improves left ventricular function in patients at risk for adverse remodeling after acute ST-segment elevation myocardial infarction: results of the reinfusion of enriched progenitor cells and infarct remodeling in acute myocardial infarction study (REPAIR-AMI) cardiac magnetic resonance imaging substudy. Am. Heart J. 157, 541-547. doi:10.1016/j.ahj.2008.11.011

Fernández-Avilés, F., Sanz-Ruiz, R., Bogaert, J., Plasencia, A. C., Gilaberte, I., Belmans, A., et al. (2018). Safety and efficacy of intracoronary infusion of allogeneic human cardiac stem cells in patients with ST-segment elevation myocardial infarction and left ventricular dysfunction. Circ. Res. 123, 579-589. doi:10.1161/circresaha.118.312823

Fischer-Rasokat, U., Assmus, B., Seeger, F. H., Honold, J., Leistner, D., Fichtlscherer, S., et al. (2009). A pilot trial to assess potential effects of selective intracoronary bone marrow-derived progenitor cell infusion in patients with nonischemic dilated cardiomyopathy. Circ. Heart Fail. 2, 417-423. doi:10.1161/circheartfailure.109.855023

Fonseca, L. M. B. d, Xavier, S. S., Castro, P. H. R. d, Lima, R. S. L., Gutfilen, B., Goldenberg, R. C. S., et al. (2011). Biodistribution of bone marrow mononuclear cells in chronic chagasic cardiomyopathy after intracoronary injection. Int. J. Cardiol. 149, 310-314. doi:10.1016/j.ijcard.2010.02.008

Goldenberg, R. C. S., Jelicks, L. A., Fortes, F. S. A., Weiss, L. M., Rocha, L. L., Zhao, D., et al. (2008). Bone marrow cell therapy ameliorates and reverses chagasic cardiomyopathy in a mouse model. J. Infect. Dis. 197, 544-547. doi:10.1086/ 526793

Goldenberg, R. C. S., Iacobas, D. A., Iacobas, S., Rocha, L.L, Fortesda, F. de S. de A., Vairo, L., et al. (2009). Transcriptomic alterations in trypanosoma cruziinfected cardiac myocytes. Microbes Infect. 11, 1140-1149. doi:10.1016/j. micinf.2009.08.009

Gowdak, L. H. W., Schettert, I. T., Rochitte, C. E., Lisboa, L. A. F., Dallan, L. A. O., César, L. A. M., et al. (2005). Cell therapy plus transmyocardial laser revascularization for refractory angina. Ann. Thorac. Surg. 80, 712-714. doi:10.1016/j.athoracsur.2005.04.080

Grajek, S., Popiel, M., Gil, L., Breborowicz, P., Lesiak, M., Czepczyński, R., et al. (2010). Influence of bone marrow stem cells on left ventricle perfusion and ejection fraction in patients with acute myocardial infarction of anterior wall: randomized clinical trial: impact of bone marrow stem cell intracoronary infusion on improvement of microcirculation. Eur. Heart. J. 31, 691-702. doi:10.1093/eurheartj/ehp536

Hamamoto, H., Gorman, J. H., Ryan, L. P., Hinmon, R., Martens, T. P., Schuster, M. D., et al. (2009). Allogeneic mesenchymal precursor cell therapy to limit remodeling after myocardial infarction: the effect of cell dosage. Ann. Thorac. Surg. 87, 794-801. doi:10.1016/j.athoracsur.2008.11.057

Hare, J. M., Fishman, J. E., Gerstenblith, G., DiFede Velazquez, D. L., Zambrano, J. P., Suncion, V. Y., et al. (2012). Comparison of allogeneic vs autologous bone marrow-derived mesenchymal stem cells delivered by transendocardial injection in patients with ischemic cardiomyopathy: the POSEIDON randomized trial. JAMA. 308, 2369-2379. doi:10.1001/jama.2012.25321

Hare, J. M., DiFede, D. L., Castellanos, A. M., Florea, V., Landin, A. M., ElKhorazaty, J., et al. (2016). Randomized comparison of allogeneic Vs. autologous mesenchymal stem cells for non-lschemic dilated cardiomyopathy: POSEIDON-DCM trial. J. Am. Coll. 69, 526-537. doi:10. 1016/j.jacc.2016.11.009

Heldring, N., Mäger, I, Wood, M. J. A., Blanc, K. L., and Andaloussi, S. E. L. (2015). Therapeutic potential of multipotent mesenchymal stromal cells and their extracellular vesicles. Hum. Gene. Ther. 26, 506-517. doi:10.1089/hum. 2015.072
Henry, T. D., Traverse, J. H., Hammon, B. L., East, C. A., Bruckner, B., Remmers, A. E., et al. (2014). Safety and efficacy of ixmyelocel-T: an expanded, autologous multi-cellular therapy, in dilated cardiomyopathy. Circ. Res. 115, 730-737. doi:10.1161/circresaha.115.304554

Henry, T. D., Losordo, D. W., Traverse, J. H., Schatz, R. A., Jolicoeur, E. M., Schaer, G. L., et al. (2018). Autologous CD34+ cell therapy improves exercise capacity, angina frequency and reduces mortality in no-option refractory angina: a patient-level pooled analysis of randomized double-blinded trials. Eur. Heart. J. 39, 2208-2212. doi:10.1093/eurheartj/ehx764

Hofmann, M., Wollert, K. C., Meyer, G. P., Menke, A., Arseniev, L., Hertenstein, B., et al. (2005). Monitoring of bone marrow cell homing into the infarcted human myocardium. Circulation 111, 2198-2202. doi:10.1161/01.cir.0000163546. 27639.aa

Honold, J., Fischer-Rasokat, U., Lehmann, R., Leistner, D. M., Seeger, F. H., Schachinger, V., et al. (2012). G-CSF stimulation and coronary reinfusion of mobilized circulating mononuclear proangiogenic cells in patients with chronic ischemic heart disease:five-year results of the TOPCARE-G-CSF trial. Cell Transplant. 21, 2325-2337. doi:10.3727/096368912x654957

Iacobas, D. A., Iacobas, S., Tanowitz, H. B., Carvalho, A. C. D., and Spray, D. C. (2018). Functional genomic fabrics are remodeled in a mouse model of chagasic cardiomyopathy and restored following cell therapy. Microbes. Infect. 20, 185-195. doi:10.1016/j.micinf.2017.11.003

Janssens, S., Dubois, C., Bogaert, J., Theunissen, K., Deroose, C., Desmet, W., et al. (2006). Autologous bone marrow-derived stem-cell transfer in patients with ST-segment elevation myocardial infarction: double-blind, randomised controlled trial. Lancet. 367, 113-121. doi:10.1016/s01406736(05)67861-0

JasminJelicks, L. A., Koba, W., Tanowitz, H. B., Mendez-Otero, R., Campos de Carvalho, A. C., et al. (2012). Mesenchymal bone marrow cell therapy in a mouse model of chagas disease. where do the cells go?. PLoS. Negl. Trop. Dis. 6, e1971, doi:10.1371/journal.pntd.0001971

JasminJelicks, L. A., Tanowitz, H. B., Peters, V. M., Mendez-Otero, R., Carvalho, A. C. C. D., et al. (2014). Molecular imaging, biodistribution and efficacy of mesenchymal bone marrow cell therapy in a mouse model of chagas disease. Microbes Infect. 16, 923-935. doi:10.1016/j.micinf.2014.08.016

Kastrup, J., Haack-Sørensen, M., Juhl, M., Søndergaard, R., Follin, B., Lund, L., et al. (2017). Cryopreserved off-the-shelf allogeneic adipose-derived stromal cells for therapy in patients with ischemic heart disease and heart failure-a safety study. Stem. Cells. Transl. Med. 6, 1963-1971. doi:10.1002/sctm.17-0040

Lipinski, M. J., Biondi-Zoccai, G. G., Abbate, A., Khianey, R., Sheiban, I., Bartunek, J., et al. (2007). Impact of intracoronary cell therapy on left ventricular function in the setting of acute myocardial infarction: a collaborative systematic review and meta-analysis of controlled clinical trials. J. Am. Coll. Cardiol. 50, 1761-1767. doi:10.1016/j.jacc.2007.07.041

Liu, Y-W., Chen, B., Yang, X., Fugate, J. A., Kalucki, F. A., Futakuchi-Tsuchida, A., et al. (2018). Human embryonic stem cell-derived cardiomyocytes restore function in infarcted hearts of non-human primates. Nat. Biotechnol. 36, 597-605. doi:10.1038/nbt.4162

Losordo, D. W., Schatz, R. A., White, C. J., Udelson, J. E., Veereshwarayya, V., Durgin, M., et al. (2007). Intramyocardial transplantation of autologous CD34+ stem cells for intractable angina: a phase I/IIa double-blind, randomized controlled trial. Circulation. 115, 3165-3172. doi:10.1161/circulationaha.106. 687376

Losordo, D. W., Henry, T. D., Davidson, C., Sup Lee, J., Costa, M. A., Bass, T., et al. (2011). Intramyocardial, autologous CD34+ cell therapy for refractory angina. Circ. Res. 109, 428-436. doi:10.1161/circresaha.111.245993

Lunde, K., Solheim, S., Aakhus, S., Arnesen, H., Abdelnoor, M., Egeland, T., et al. (2006). Intracoronary injection of mononuclear bone marrow cells in acute myocardial infarction. N. Engl. J. Med. 355, 1199-1209. doi:10.1056/ nejmoa055706

Makkar, R. R., Smith, R. R., Cheng, K., Malliaras, K., Thomson, L. E., Berman, D., et al. (2012). Intracoronary cardiosphere-derived cells for heart regeneration after myocardial infarction (CADUCEUS): a prospective, randomised phase 1 trial. Lancet. 379, 895-904. doi:10.1016/s0140-6736(12)60195-0

Malliaras, K., Makkar, R. R., Smith, R. R., Cheng, K., Wu, E., Bonow, R. O., et al. (2014). Intracoronary cardiosphere-derived cells after myocardial infarction: evidence of therapeutic regeneration in the final 1-year results of the CADUCEUS trial (CArdiosphere-Derived aUtologous stem CElls to reverse 
ventricUlar dySfunction). J. Am. Coll. Cardiol. 63, 110-122. doi:10.1016/j.jacc. 2013.08.724

Martino, H. F., Oliveira, P. S., Souza, F. C., Costa, P. C., Assunção E Silva, E., Villela, R., et al. (2010). A safety and feasibility study of cell therapy in dilated cardiomyopathy. Braz. J. Med. Biol. Res. 43, 989-995. doi:10.1590/s0100879x2010007500093

Martino, H., Brofman, P., Greco, O., Bueno, R., Bodanese, L., Clausell, N., et al. (2015). Multicentre, randomized, double-blind trial of intracoronary autologous mononuclear bone marrow cell injection in non-ischemic dilated cardiomyopathy (the dilated cardiomyopathy arm of the MiHeart study). Eur. Heart J. 36, 2898-2904. doi:10.1093/eurheartj/ehv477

Martin-Rendon, E., Brunskill, S. J., Hyde, C. J., Stanworth, S. J., Mathur, A., and Watt, S. M. (2008). Autologous bone marrow stem cells to treat acute myocardial infarction: a systematic review. Eur. Heart J. 29, 1807-1818. doi:10.1093/eurheartj/ehn220

Mathiasen, A. B, Qayyum, A. A, Jørgensen, E., Helqvist, S., Fischer-Nielsen, A., Kofoed, K. F., et al. (2015). Bone marrow-derived mesenchymal stromal cell treatment in patients with severe ischemic heart failure: a randomized placebocontrolled trial (MSC-HF trial). Eur. Heart J. 36, 1744-1753. doi:10.1093/ eurheartj/ehv136

Mathur, A., Fernández-Avilés, F., Bartunek, J., Belmans, A., Crea, F., Dowlut, S., et al. (2020). The effect of intracoronary infusion of bone marrow-derived mononuclear cells on all-cause mortality in acute myocardial infarction: the BAMI trial. Eur. Heart J. 41, 3702-3710. doi:10.1093/eurheartj/ehaa651

Menasché, P., Hagège, A. A., Scorsin, M., Pouzet, B., Desnos, M., Duboc, D., et al. (2001). Myoblast transplantation for heart failure. Lancet. 357, 279-280. doi:10. 1016/s0140-6736(00)03617-5

Menasché, P., Vanneaux, V., Hagège, A., Bel, A., Cholley, B., Cacciapuoti, I., et al. (2015). Human embryonic stem cell-derived cardiac progenitors for severe heart failure treatment: first clinical case report: Figure 1. Eur. Heart J. 36, 2011-2017. doi:10.1093/eurheartj/ehv189

Menasché, P., Vanneaux, V., Hagège, A., Bel, A., Cholley, B., Parouchev, A., et al. (2018). Transplantation of human embryonic stem cell-derived cardiovascular progenitors for severe ischemic left ventricular dysfunction. J. Am. Coll. Cardiol. 71, 429-438. doi:10.1016/j.jacc.2017.11.047

Mozid, A., Yeo, C., Arnous, S., Ako, E., Saunders, N., Locca, D., et al. (2014). Safety and feasibility of intramyocardial versus intracoronary delivery of autologous cell therapy in advanced heart failure: the REGENERATE-IHD pilot study. Regen. Med. 9, 269-278. doi:10.2217/rme.14.3

Neglia, D., Michelassi, C., Trivieri, M. G., Sambuceti, G., Giorgetti, A., Pratali, L., et al. (2002). Prognostic role of myocardial blood flow impairment in idiopathic left ventricular dysfunction. Circulation. 105, 186-193. doi:10.1161/hc0202. 102119

Nicolau, J. C., Furtado, R. H. M., Silva, S. A., Rochitte, C. E., Rassi, A., Moraes, J. B. M. C., et al. (2018). Stem-cell therapy in ST-segment elevation myocardial infarction with reduced ejection fraction: a multicenter, double-blind randomized trial. Clin. Cardiol. 41, 392-399. doi:10.1002/clc.22882

Patel, A. N., Henry, T. D., Quyyumi, A. A., Schaer, G. L., Anderson, R. D., Toma, C., et al. (2016). Ixmyelocel-T for patients with ischemic heart failure: a prospective randomised double-blind trial. Lancet. 387, P2412-P2421. doi:10.1016/S01406736(16)30137-4

Perin, E. C., Dohmann, H. F. R., Borojevic, R., Silva, S. A., Sousa, A. L. S., Mesquita, C. T., et al. (2003). Transendocardial, autologous bone marrow cell transplantation for severe, chronic ischemic heart failure. Circulation. 107, 2294-2302. doi:10.1161/01.cir.0000070596.30552.8b

Perin, E. C., Willerson, J. T., Pepine, C. J., Henry, T. D., Ellis, S. G., Zhao, D. X., et al. (2012). Effect of transendocardial delivery of autologous bone marrow mononuclear cells on functional capacity, left ventricular function, and perfusion in chronic heart failure: the FOCUS-CCTRN trial. JAMA. 307, 1717-1726. doi:10.1001/jama.2012.418

Perin, E. C., Sanz-Ruiz, R., Sánchez, P. L., Lasso, J., Pérez-Cano, R., Alonso-Farto, J. C., et al. (2014). Adipose-derived regenerative cells in patients with ischemic cardiomyopathy: The PRECISE trial. Am. Heart J. 168, 88-95.e2. doi:10.1016/j. ahj.2014.03.022

Perin, E. C., Borow, K. M., Silva, G. V., DeMaria, A. N., Marroquin, O. C., Huang, P. P., et al. (2015). A phase II dose-escalation study of allogeneic mesenchymal precursor cells in patients with ischemic or nonischemic heart failure. Circ. Res. 117, 576-584. doi:10.1161/circresaha.115.306332
Ponikowski, P., Voors, A. A., Anker, S. D., Bueno, H., Cleland, J. G. F., Coats, A. J. S., et al. (2016). 2016 ESC Guidelines for the diagnosis and treatment of acute and chronic heart failure: the task force for the diagnosis and treatment of acute and chronic heart failure of the European Society of Cardiology (ESC) developed with the special contribution of the Heart Failure Association (HFA) of the ESC. Eur. Heart J. 37, 2129-2000. doi:10.1093/eurheartj/ehw128

Povsic, T. J., Henry, T. D., Traverse, J. H., Fortuin, F. D., Schaer, G. L., Kereiakes, D. J., et al. (2016). The RENEW trial: efficacy and safety of intramyocardial autologous $\mathrm{CD} 34(+)$ cell administration in patients with refractory angina. JACC. Cardiovasc. Interv. 9, 1576-1585. doi:10.1016/j.jcin.2016.05.003

Quyyumi, A. A., Vasquez, A., Kereiakes, D. J., Klapholz, M., Schaer, G. L., AbdelLatif, A., et al. (2017). PreSERVE-AMI: a randomized, double-blind, placebocontrolled clinical trial of intracoronary administration of autologous CD34+ cells in patients with left ventricular dysfunction post STEMI. Circ Res 120, 324-331. doi:10.1161/CIRCRESAHA.115.308165

Sanganalmath, S. K., and Bolli, R. (2013). Cell therapy for heart failure: a comprehensive overview of experimental and clinical studies, current challenges, and future directions. Circ. Res. 113, 810-834. doi:10.1161/ circresaha.113.300219

Sant'Anna, R. T., Fracasso, J., Valle, F. H., Castro, I., Nardi, N. B., Sant'Anna, J. R. M., et al. (2014). Direct intramyocardial transthoracic transplantation of bone marrow mononuclear cells for non-ischemic dilated cardiomyopathy: INTRACELL, a prospective randomized controlled trial. Rev. Bras. Cir. Cardiovasc. 29, 437-447. doi:10.5935/1678-9741.20140091

Santos, R. D., Rassi, S., Feitosa, G., Grecco, O. T., Rassi, A., da Cunha, A. B., et al. (2012). Cell therapy in chagas cardiomyopathy (chagas arm of the multicenter randomized trial of cell therapy in cardiopathies study): a multicenter randomized trial. Circulation. 125, 2454-2461. doi:10.1161/circulationaha. 111.067785

Schächinger, V., Erbs, S., Elsässer, A., Haberbosch, W., Hambrecht, R., Hölschermann, H., et al. (2006a). Improved clinical outcome after intracoronary administration of bone-marrow-derived progenitor cells in acute myocardial infarction: final 1-year results of the REPAIR-AMI trial. Eur. Heart J. 27, 2775-2783. doi:10.1093/eurheartj/ehl388

Schächinger, V., Erbs, S., Elsässer, A., Haberbosch, W., Hambrecht, R., Hölschermann, H., et al. (2006b). Intracoronary bone marrow-derived progenitor cells in acute myocardial infarction. N. Engl. J. Med. 355, 1210-1221. doi:10.1056/nejmoa060186

Seth, S., Narang, R., Bhargava, B., Ray, R., Mohanty, S., Gulati, G., et al. (2006). Percutaneous intracoronary cellular cardiomyoplasty for nonischemic cardiomyopathy: clinical and histopathological results: the first-in-man ABCD (Autologous Bone Marrow Cells in Dilated Cardiomyopathy) trial. J. Am. Coll. Cardiol. 48, 2350-2351. doi:10.1016/j.jacc.2006.07.057

Seth, S., Bhargava, B., Narang, R., Ray, R., Mohanty, S., Gulati, G., et al. (2010). The ABCD (Autologous Bone Marrow Cells in Dilated Cardiomyopathy) trial a long-term follow-up study. J. Am. Coll. Cardiol. 55, 1643-1644. doi:10.1016/j. jacc.2009.11.070

Shiba, Y., Gomibuchi, T., Seto, T., Wada, Y., Ichimura, H., Tanaka, Y., et al. (2016). Allogeneic transplantation of iPS cell-derived cardiomyocytes regenerates primate hearts. Nature. 538, 388-391. doi:10.1038/nature19815

Soares, M. B. P., Lima, R. S., Rocha, L. L., Takyia, C. M., Pontes-de-Carvalho, L., de Carvalho, A. C., et al. (2004). Transplanted bone marrow cells repair heart tissue and reduce myocarditis in chronic chagasic mice. Am. J. Pathol. 164, 441-447. doi:10.1016/s0002-9440(10)63134-3

Soares, M. B. P., Lima, R. S., Souza, B. S. F., Vasconcelos, J. F., Rocha, L. L., Dos Santos, R. R., et al. (2011). Reversion of gene expression alterations in hearts of mice with chronic chagasic cardiomyopathy after transplantation of bone marrow cells. Cell Cycle. 10, 1448-1455. doi:10.4161/cc.10.9.15487

Spoel, T. I. G., Lee, J. C., Vrijsen, K., Sluijter, J. P., Cramer, M. J., Doevendans, P. A., et al. (2011). Non-surgical stem cell delivery strategies and in vivo cell tracking to injured myocardium. Int. J. Cardiovasc. Imaging. 27, 367-383. doi:10.1007/ s10554-010-9658-4

Strauer, B. E., Brehm, M., Zeus, T., Köstering, M., Hernandez, A., Sorg, R. V., et al. (2002). Repair of infarcted myocardium by autologous intracoronary mononuclear bone marrow cell transplantation in humans. Circulation. 106, 1913-1938. doi:10.1161/01.cir.0000034046.87607.1c

Suncion, V. Y., Ghersin, E., Fishman, J. E., Zambrano, J. P., Karantalis, V., Mandel, N., et al. (2014). Does transendocardial injection of mesenchymal stem cells 
improve myocardial function locally or globally?: an analysis from the percutaneous stem cell injection delivery effects on neomyogenesis (POSEIDON) randomized trial. Circ. Res. 114, 1292-1301. doi:10.1161/ circresaha.114.302854

Sürder, D., Manka, R., Lo Cicero, V., Moccetti, T., Rufibach, K., Soncin, S., et al. (2013). Intracoronary injection of bone marrow-derived mononuclear cells early or late after acute myocardial infarction. Circulation. 127, 1968-1979. doi:10.1161/CIRCULATIONAHA.112.001035

Sürder, D., Manka, R., Moccetti, T., Lo Cicero, V. L, Emmert, M. Y., Klersy, C., et al. (2016). Effect of bone marrow-derived mononuclear cell treatment, early or late after acute myocardial infarction. Circ. Res. 119, 481-490. doi:10.1161/ CIRCRESAHA.116.308639

Tanowitz, H. B., Machado, F. S., Jelicks, L. A., Shirani, J., de Carvalho, A. C., Spray, DC, et al. (2009). Perspectives on trypanosoma cruzi-induced heart disease (Chagas disease). Prog. Cardiovasc. Dis. 51, 524-539. doi:10.1016/j.pcad.2009.02.001

Teerlink, J. R., Metra, M., Filippatos, G. S., Davison, B. A., Bartunek, J., Terzic, A., et al. (2017). Benefit of cardiopoietic mesenchymal stem cell therapy on left ventricular remodelling: results from the congestive heart failure cardiopoietic regenerative therapy (CHART-1) study. Eur. J. Heart Fail. 19, 1520-1529. doi:10.1002/ejhf.898

Traverse, J. H., Henry, T. D., Ellis, S. G., Pepine, C. J., Willerson, J. T., Zhao, D. X. M., et al. (2011). Effect of intracoronary delivery of autologous bone marrow mononuclear cells 2 to 3 weeks following acute myocardial infarction on left ventricular function: the lateTIME randomized trial. JAMA. 306, 2110-1119. doi:10.1001/jama.2011.1670

Traverse, J. H., Henry, T. D., Pepine, C. J., Willerson, J. T., Zhao, D. X. M., Ellis, S. G., et al. (2012). Effect of the use and timing of bone marrow mononuclear cell delivery on left ventricular function after acute myocardial infarction: the tIME randomized trial. JAMA. 308, 2380-2389. doi:10.1001/jama.2012.28726

Vicinanza, C., Aquila, I., Cianflone, E., Scalise, M., Marino, F., Mancuso, T., et al. (2018). Kitcre knock-in mice fail to fate-map cardiac stem cells. Nature. 555, E1-E5. doi:10.1038/nature25771

Vilas-Boas, F., Feitos, G. S., Soares, M. B. P., Mota, A., Pinho-Filho, J. A., Almeida, A. J. G., et al. (2006). Resultados iniciais do transplante de células de medula óssea para o miocárdio de pacientes com insuficiência cardíaca de etiologia chagásica. Arq. Bras. Cardiol. 87, 159-166. doi:10.1590/s0066782x2006001500014

Vilas-Boas, F., Feitosa, G., Soares, M. B., Pinho-Filho, J. A, Mota, A. C. A., Almeida, A. J. G., et al. (2011). Bone marrow cell transplantation in chagas' disease heart failure: report of the first human experience. Arq. Bras. Cardiol. 96, 325-331. doi:10.1590/s0066-782x2011005000028
Vrtovec, B., Poglajen, G., Sever, M., Lezaic, L., Domanovic, D., Cernelc, P., Haddad, F., et al. (2011). Effects of intracoronary stem cell transplantation in patients with dilated cardiomyopathy. J. Card. Fail. 17, 272-281. doi:10.1016/j.cardfail. 2010.11.007

Vrtovec, B., Poglajen, G., Lezaic, L., Sever, M., Domanovic, D., Cernelc, P., et al. (2013a). Effects of intracoronary CD34+ stem cell transplantation in nonischemic dilated cardiomyopathy patients: 5-year follow-up. Circ. Res. 112, 165-173. doi:10.1161/circresaha.112.276519

Vrtovec, B., Poglajen, G., Lezaic, L., Sever, M., Socan, A., Domanovic, D., et al. (2013b). Comparison of transendocardial and intracoronary CD34+ cell transplantation in patients with nonischemic dilated cardiomyopathy. Circulation. 128, S42-S49. doi:10.1161/circulationaha.112.000230

Wollert, K. C., Meyer, G. P., Lotz, J., Ringes-Lichtenberg, S., Lippolt, P., Breidenbach, C., et al. (2004). Intracoronary autologous bone-marrow cell transfer after myocardial infarction: the BOOST randomised controlled clinical trial. Lancet. 364, 141-148. doi:10.1016/s0140-6736(04)16626-9

Wollert, K. C., Meyer, G. P., Müller-Ehmsen, J., Tschöpe, C., Bonarjee, V., Larsen, A. I., et al. (2017). Intracoronary autologous bone marrow cell transfer after myocardial infarction: the BOOST-2 randomised placebo-controlled clinical trial. Eur. Heart J. 38, 2936-2943. doi:10.1093/eurheartj/ehx188

Yancy, C. W., Jessup, M., Bozkurt, B., Butler, J., Casey, D. E., Colvin, M. M., et al. (2016). 2016 ACC/AHA/HFSA focused update on new pharmacological therapy for heart failure: an update of the 2013 ACCF/AHA guideline for the management of heart failure: a report of the American College of Cardiology/American heart association task force on clinical practice guidelines and the heart failure society of America. J. Am. Coll. Cardiol. 68, 1476-1488. doi:10.1161/cir.000000000000043510.1016/j.jacc.2016.05.011

Ziaeian, B., and Fonarow, G. C. (2016). Epidemiology and aetiology of heart failure. Nat Rev Cardiol 13, 368-378. doi:10.1038/nrcardio.2016.25

Conflict of Interest: The authors declare that the research was conducted in the absence of any commercial or financial relationships that could be construed as a potential conflict of interest.

Copyright (c) 2021 Campos de Carvalho, Kasai-Brunswick and Bastos Carvalho. This is an open-access article distributed under the terms of the Creative Commons Attribution License (CC BY). The use, distribution or reproduction in other forums is permitted, provided the original author(s) and the copyright owner(s) are credited and that the original publication in this journal is cited, in accordance with accepted academic practice. No use, distribution or reproduction is permitted which does not comply with these terms. 